\title{
Law reform dealing with blood, tissues, organ transplants and health research: A lagging legal framework that is strangling innovation
}

Law is an important component of the regulation of the use of the human body or body parts, new medical developments, and research on human subjects. Complex moral, ethical and public policy considerations must often be balanced when determining the boundaries between academic freedom, promoting public health, and protecting patients and research participants. Despite the implications of revolutionary scientific developments, the South African parliament has struggled to create a principled framework for biomedicine and research.

Blood, blood products, tissues and gametes were, until 1 March 2012, regulated by the Human Tissues Act. ${ }^{1}$ This old Act was hopelessly inadequate to deal with many innovations such as pre-implantation diagnosis. ${ }^{2}$ To address this vacuum, parliament passed the National Health Act in 2003, ${ }^{3}$ and implemented most of it in $2005 .^{4}$ The outstanding parts of chapter 8, dealing with blood, blood products, tissues and gametes, were operationalised this year, ${ }^{5}$ and accompanying Regulations were published in the Government Gazette. ${ }^{6}$

There was little legal regulation of health research until the National Health Act, ${ }^{3}$ which created a comprehensive, national ethical-legal framework. Like chapter 8, only parts of chapter 9 on health research and information were implemented in $2005,{ }^{4}$ and the rest came into operation on 1 March 2012. ${ }^{5}$ However, unlike the provisions on blood, blood products, tissues and gametes, no regulations have been published to guide the implementation of the section on research with human subjects.

\section{Regulation of blood, blood products, tissues and gametes in humans}

Chapter 8 of the National Health $\mathrm{Act}^{3}$ and its accompanying Regulations $^{6}$ create a comprehensive new framework for regulating, among others, the removal and use of blood, blood products and gametes from both living and dead persons. In this issue ${ }^{7}$ McQuoid-Mason points out that the new provisions have widespread implications for doctors assisting patients or their relatives with tissue donations, organ transplants and donations of human bodies or tissues, revocations of donations, and confidentiality regarding such donations. Pepper ${ }^{8}$ also notes that the reforms introduced by the operationalisation of chapter 8 are a welcome step towards 'partial relief from the regulatory vacuum'; although the new framework is imperfect, it is workable. McQuoid-Mason ${ }^{7}$ argues that this is partly due to the Regulations dealing with some issues not addressed by the National Health Act, e.g. they deal with recent concerns regarding the unlawful sale of kidneys to foreign patients, by prohibiting transplants into non-South African citizens unless ministerial permission is obtained. However, gaps remain in the reformed framework, and inaccuracies in the Regulations create new complexities. ${ }^{8}$ An example is the definition of transgenic cells in the Regulations, ${ }^{9}$ which are described as 'cells derived from a species other than human' - this is incorrect, as cells derived from other species are termed 'xenogeneic'.

Sadly, the above means that despite this law reform being less than 6 months old, it already lags behind medical advances. Furthermore, the gap between the law and science will widen further as new advances challenge the limited framework. Pepper therefore calls for reform of the National Health Act and its accompanying Regulations. ${ }^{8}$

\section{The new framework for the regulation of health research with human subjects}

The implementation of parts of chapter 9 of the National Health Act in $2005^{4}$ heralded a new era in research regulation in South Africa. These created procedural protections for research participants, such as requiring ethical approval for all forms of health research, and giving the National Health Research Ethics Council the authority to issue ethical guidelines. Although this framework was welcomed, there have also been criticisms of it. In this issue Britz and Le Roux-Kemp ${ }^{10}$ identify key shortcomings in the national ethical guidelines regulating informed consent to participation in clinical trials and call for these to be revised, updated, and aligned with international guidance.

The operationalisation of section 71 of the National Health Act on 1 March 2012 has completed our ethical-legal framework by introducing substantive legal norms on how health research with human subjects should be undertaken, providing inter alia that research may only be undertaken if: $(i)$ it is done in the prescribed manner; (ii) written consent is obtained; (iii) it can be shown that therapeutic research involving minors is in their best interests; (iv) ministerial consent is obtained for non-therapeutic research involving minors; and $(v)$ consent is obtained from parents or legal guardians for all research involving minors. ${ }^{3}$ However, no regulations have been published providing detail on, for example, how to obtain ministerial consent for non-therapeutic research involving minors.

Operationalising section 71 of the National Health Act has resulted in the law lagging behind science in terms of its conceptualisation of when and how human subjects should participate in health research, and has also strangled innovation. For example, Karim et $a l$. have set out the public health arguments for why it is urgent that adolescents participate in research towards developing new HIVprevention technologies. ${ }^{11}$ However, given the restrictive framework created by section 71 , such studies will be difficult to undertake, as it is unclear, for example, how ministerial consent will be obtained. There is also a disparate impact on social science studies, as the new framework prohibits independent consent by minors and limits the authority to provide proxy consent to parents or legal guardians. The administrative burden of obtaining ministerial consent for low- or no-risk studies may also limit their feasibility. ${ }^{12}$

Regulations on how to implement section 71 are urgently needed. In the longer term, law reform is required which creates an enabling environment that facilitates appropriate research and adequately protects research participants.

The implementation of the final aspects of the National Health Act should be good news - however, it isn't, as the Minister of Health has ushered in a new legal framework that already lags behind scientific developments, and is strangling much-needed innovation in health Political commitment is required to look to the future and ensure that there is synergy between unfolding scientific developments, public health and human rights.

\section{Ann Strode}

School of Law

University of KwaZulu-Natal 


\section{EDITORIAL}

Corresponding author: A Strode (strodeA@ukzn.ac.za)

1. Human Tissues Act, No. 65 of 1983

2. Strode A, Soni S. Pre-implantation diagnosis to create 'saviour siblings': A critical discussion of the current and future legal frameworks in South Africa. S Afr Med J 2012;102(1):21.

3. National Health Act, No. 61 of 2003 .

4. Government Gazette No. 27503, 18 April 2005

5. Proclamation No. 11 in Government Gazette No. 35081, 27 February 2012.

6. Government Notices R175-R183 in Government Gazette No. 35099, 2 March 2012.

7. McQuoid-Mason D. Human tissue and organ transplant provisions: Chapter 8 of the National Health Act and its Regulations, in effect from March 2012 - what doctors must know. S Afr Med J 2012;102(9):733-735 (this issue). [http://dx.doi.org/10/7196.SAMJ.6047]

8. Pepper MS. Partial relief from the regulatory vacuum involving human tissues through the enactmen of chapter 8 of the National Health Act and Regulations thereto. S Afr Med J 2012;102(9):736-737. [http://dx.doi.org/10/7196.SAM].5940]
9. Regulations relating to the Use of Human Biological Material in Government Notice R177 of Government Gazette No. 35099, 2 March 2012.

10. Britz R, Le Roux-Kemp A. Voluntary informed consent and good clinical practice for clinical research in South Africa: Ethical and legal perspectives.S Afr Med J 2012;102(9):746-748. [http://dx.doi. org/10/7196.SAMJ.5498]

11. Abdool Karim Q, Khamny ABM, Frohlich JA, et al. HIV incidence in young girls in KwaZulu-Natal South Africa - public health imperative for the inclusion in HIV biomedical intervention trials AIDS Behav 2012; 23 May (epub ahead of print). http://www.springerlink.com/content/03343330413j2055/ fulltext.pdf (accessed 8 August 2012). [http://dx.doi.org/10.1007/s10461-012-0209-y]

12. Strode A, Slack C, Wassenaar D, Singh J. One step forward, two steps back: Requiring ministerial approval for all 'non-therapeutic' health research with minors. S Afr Med J 2007;97(3):200-202.

S Afr Med J 2012;102(9):741-742. DOI:10.7196/SAMJ.6199 